\title{
PHYSICAL AND MECHANICAL CHARACTERISTICS OF EDIBLE FILM BASED ON CASSAVA PEEL STARCH
}

\author{
Ahmad Wira Wasistha'), Muhammad Reza Sukma Dika²), Annisa' Sakina Aulia3), \\ Norazkya Mutiara Samudra4), Desiana Nuriza Putri5) \\ 1) Faculty of Agriculture and Animal Science, Food Technology Department, University of Muhammadiyah \\ Malang, Jl. Raya Tlogomas No.246, Malang, 65144, Indonesia, (0341) 464318, \\ email: desiana@umm.ac.id
}

\begin{abstract}
Cassava peel is an agro-industrial waste that is not used or not recycled. Based on the carbohydrate content of cassava peel, which is $50 \%$ of the weight of the peel, so that the cassava peel can be used as an ingredient for making edible films. The edible film is a thin layer made of natural ingredients that are safe for consumption. The biodegradable nature and can be used in this edible makes edibles used because they can be an alternative to synthetic plastics and are environmentally friendly. The purpose of this study was to determine the physical properties and mechanisms of the edible film of cassava peel starch. This study used a simple randomized block design (RBD) with 3 levels, namely A1(2\%), A2(4\%), A3(6\%) with 3 replications. Research data on cassava peel characteristics showed water content (14.62\%), starch content $(73.29 \%)$, amylose content (21.02\%), amylopectin content (52.27\%), and HCN content (7.01\%). \%). The results of the edible physical and mechanical properties showed the value of tensile strength $0.08-0.37 \mathrm{Mpa}$, thickness 0.09 $0.17 \mathrm{~mm}$, WVTR $0.26-0.39 \mathrm{~g} / \mathrm{m} 2 /$ Day, and elongation $31,86-56.43 \%$.
\end{abstract}

Keywords: Edible film, physical, mechanical, peel cassava strach

\section{INTRODUCTION}

The use of edible films as food product packaging is one of the steps that can be taken to extend the shelf life of a food product. The edible film is a thin sheet resembling packaging made from natural materials that are non-toxic and very practical, so they are safe for consumption. The essential ingredients of edible films such as proteins, hydrocolloids, and carbohydrates have been widely studied, such as tuber starch, pectin, gelatin, and collagen (Wulandari et al., 2015). Based on the composition of manufacture, edible films from materials containing polysaccharides (carbohydrates), proteins, and lipids have the advantages of being biocompatible, biodegradable, safe for consumption, aesthetic appearance, and have properties as a barrier to oxygen and physical stress during transportation and storage (Winarti, 2012).

Polysaccharides used for edible films are starch consisting of amylose and amylopectin. Starch can be used as an edible film is because starch is a hydrocolloid compound that can form a firm layer (Sarofa, 2012). Amylose affects the edible's strength and density, while the edible's stability is influenced by amylopectin (Ginting, 2012). The starch group is made from foodstuffs sourced from carbohydrates, namely cassava, sweet potatoes, and corn. Therefore, one of the starches that can be used to manufacture edible films is derived from cassava peel starch.

Cassava production in 2015 was abundant, namely $21,801,415$ tons (BPS, 2015). The higher the cassava production obtained, the higher the cassava peel produced. According to Liu (2005), most of the carbohydrate content in cassava peel is $50 \%$ of the weight of the skin, while the starch content itself is $44-59 \%$. The percentage of cassava peels produced after being hulled is approximately $20 \%$, so that when the cassavabased processing industry utilizes $100 \mathrm{~kg}$ of cassava in a day, the waste generated is 20 kg/day (Rahayu et al., 2019). The HCN content 
in cassava peel is higher when compared to the tuber flesh; a high HCN content can be seen through its bitter taste; if it tastes sweet, the HCN content is low (Sari, 2018). Therefore, the content of $\mathrm{HCN}$ in cassava peels is very high, which is 18.0 - 309 ppm per 100 grams of cassava peel (Richana, 2013). High HCN content can be reduced by immersion. According to Richana (2012), cyanide levels can be removed during the soaking, boiling, drying, and fermentation processes. (Irzam, 2014) research concluded that in the immersion process, water would cause the linamarin compound to hydrolyze and form cyanide acid, which is soluble in water. When the soaking water is replaced, the watersoluble HCN will also be wasted along with the water, so the average measured $\mathrm{HCN}$ level is low.

Previous edible film research conducted by (Alfian, 2020) is the manufacture of edible cassava peel starch using sorbitol plasticizer with citric acid. Research data using edible film carrageenan obtained the highest value of water resistance of $72.72 \%$, the tensile strength of $2.3069 \mathrm{MPa}$, and the value of percent elongation of $29.84 \%$. The study results using the addition of $1 \%$ citric acid edible film obtained the highest value of water resistance value of $80.56 \%$, elongation value of $31.88 \%$, and tensile strength of $2.3069 \mathrm{MPa}$. This research aims to know the characteristics of physical and mechanical properties from edible film based on cassava starch, determine the optimum starch concentration in edible, and can be applied to food commodities.

\section{MATERIALS AND METHODS}

\subsection{Materials}

The material used in this study is cassava peel obtained from the chip processing industry in the Gadang area, Malang Regency, with the characteristics of cassava peels that still look fresh, white, pink and odorless, glycerol, aquades, CMC (Carboxy Methyl Cellulose), silica gel, and rubber obtained from chemical stores.
The tools used in this study are beakers, measuring cups, thermometers, baking sheets, hot plates, cabinet dryers, spatulas, analytical scales, stainless steel spoons, 80 mesh sieves, $\mathrm{PP}$ plastic, a set of tensile strength tests (FG/SPAG 01 /2650 texture analyzer), glass jar, $\mathrm{NaCL}$ stand to gain water vapor transmission rate of edible film, porcelain exchanger, cuvette, aluminum foil, and screw micrometer.

\subsection{Methods}

Cassava Peel Extraction (Yudiyanti, 2020)

Cassava peel waste was washed using running water and rinsed with water for 15 minutes until the soaking water was slightly clear, then soaked in water for 24 hours. This washing and soaking process aims to remove dirt on the cassava peel, reduce the sap, reduce the vibration sensation and reduce the HCN content in the cassava peel. Next, cassava peel was crushed using a blender and added $100 \mathrm{ml}$ of water. Then the cassava peel pulp is filtered and deposited for about 24 hours. Cassava peel starch is obtained when the sediment-water is removed. Then the starch was dried in the oven for 13 hours at a temperature of $60 \mathrm{oC}$. After drying, the starch is crushed using a blender and then filtered.

\section{Amylose and Amylopectin Analysis (Martono et al, 2016)}

The first step was to make reagents (amylose and amylopectin) by preparing $0.30 \mathrm{~g}$ $\mathrm{I} 2$ and $1.20 \mathrm{~g} \mathrm{KI}$ which were weighed and dissolved in $100 \mathrm{ml}$ of $0.01 \mathrm{M} \mathrm{HCl}$ solution. Then the solution was diluted five times. The second step was making a standard amylose curve by preparing $20.0 \mathrm{mg}$ of amylose dissolved in $5 \mathrm{ml}$ of $1 \mathrm{M} \mathrm{NaOH}$. Then $5 \mathrm{ml}$ of distilled water was added. Then take $1 \mathrm{ml}$ of solution and add $5 \mathrm{ml}$ of $1 \mathrm{M} \mathrm{HCl}$. The solution is filled with distilled water until it reaches $50 \mathrm{ml}$. Next, take $5 \mathrm{ml}$ of amylose solution by adding $2 \mathrm{ml}$ of TCA (Tricholoroacetic acid) solution and $2 \mathrm{ml}$ of $\mathrm{I} 2-\mathrm{KI}$ reagent solution. Next, the absorbance of the solution was measured using a UV-VIS spectrophotometer with a 
wavelength of $630 \mathrm{~nm}$. The third step is to make a standard curve of amylopectin by weighing $25.0 \mathrm{mg}$ of amylopectin and dissolving it in $5 \mathrm{ml}$ of $1 \mathrm{M} \mathrm{NaOH}$. Finally, add $5 \mathrm{ml}$ of distilled water to the solution.

Then take $1 \mathrm{ml}$ of the solution and add 5 $\mathrm{ml}$ of $1 \mathrm{M} \mathrm{HCl}$. Then fill the solution with distilled water until the volume is $50 \mathrm{ml}$. Next, take $5 \mathrm{ml}$ of amylopectin solution and add $2 \mathrm{ml}$ of TCA (Tricholoroacetic acid) solution and $2 \mathrm{ml}$ of $\mathrm{I} 2$ $\mathrm{KI}$ reagent solution. Furthermore, the absorbance of the solution was measured using a UV-VIS spectrophotometer with a wavelength of $535 \mathrm{~nm}$. The fourth step is to measure the amylose content in the sample by weighing $20.0 \mathrm{mg}$ and dissolving it in $5 \mathrm{ml}$ of 1 $\mathrm{M} \mathrm{NaOH}$. Next, add $5 \mathrm{ml}$ of distilled water to the solution. Then take $1 \mathrm{ml}$ of the solution and add $5 \mathrm{ml}$ of $1 \mathrm{M} \mathrm{HCl}$. The solution is added with distilled water until the volume is $50 \mathrm{ml}$. Next, take $5 \mathrm{ml}$ of the solution sample and add $2 \mathrm{ml}$ of TCA (Tricholoroacetic acid) solution and $2 \mathrm{ml}$ of $12-\mathrm{KI}$ reagent solution. Next, the absorbance of the solution was measured using a UV-VIS spectrophotometer with a wavelength of 630 $\mathrm{nm}$. Amylose content was determined based on the curve and expressed in \% (w/w).

\section{HCN content (Soedarmadji et al, 1997).}

The first step is weighing 10-20 grams of the mashed sample, adding $100 \mathrm{ml}$ of distilled water in a Kjeldahl flask, and soaking it for about 2 hours. Next, add $100 \mathrm{ml}$ of distilled water and do the distillation with steam (steam distillation). The results of the distillation were put into an Erlenmeyer containing $20 \mathrm{ml}$ of $2.5 \% \mathrm{NaOH}$. After the distillate reached $150 \mathrm{ml}$, the distillation was stopped. Then the distillate was added with $8 \mathrm{ml}$ of $\mathrm{NH} 4 \mathrm{OH}, 5 \mathrm{ml}$ of $5 \% \mathrm{KI}$, and titrated with $0.02 \mathrm{~N} \mathrm{AgNO} 3$ solution until it became turbid (this turbidity can be seen when carbon black paper is placed under the Erlenmeyer).

\section{Physical Characteristics of Edible Film \\ Film Water Vapor Transmission Rate Analysis (ASTM E96/E96M16,2016)}

The edible film was cut with a diameter of $5 \mathrm{~cm}$ and then glued to a cup containing $2 \mathrm{~g}$ of silica gel using rubber; then, the cup and film were weighed as the initial weight. Then the cup was put in a jar containing $100 \mathrm{~mL}$ of $40 \%$ $\mathrm{NaCl}$ solution $(\mathrm{RH}=75 \%)$ at $25^{\circ} \mathrm{C}$. Every 24 hours for six days, the cup is weighed using an analytical balance. The cup's weight was made into a linear regression equation; the slope increase in the weight of the dish ( $g /$ day) was divided by the surface area of the film being tested (m2).

The water vapor transmission rate is calculated using the formula:

water vapor transmission $=\frac{\Delta \mathrm{W}}{\mathrm{tXA}}$

Note :

$\Delta W=$ Change in film weight after 24 hours

$\mathrm{t}=$ Times (24 hours)

$A=$ Surface area $(\mathrm{cm} 2)$

Edible Film Thickness Analysis (Yoshida dan Antunes, 2004)

Edible film samples were measured using a micrometer screw with an accuracy of $0.01 \mathrm{~mm}$ at five different places. The measurement results are averaged as the result of film thickness.

Tensile Strength and Elongation Analysis (ASTM D882-12, 2012)

Edible cassava peel starch was cut with a size of $20 \mathrm{~mm} \times 50 \mathrm{~mm}$. Universal Testing Machine to measure tensile strength and percent elongation. Tensile strength is determined by the maximum stress when the film is torn. Elongation is determined by the elongation of the film when the film is torn. The equations for tensile strength and elongation are calculated as follows:

tensile strength $(\tau)=\frac{\mathrm{F}}{\mathrm{A}}$

Note :

$\mathrm{F}=$ Compressive Force $(\mathrm{N})$

$A=$ Surface area $\left(\mathrm{cm}^{2}\right)$

Elongation $(\%)=\frac{\mathrm{d} \text { after }-\mathrm{d} \text { before }(\mathrm{mm})}{\mathrm{d} \text { before }(\mathrm{mm})} \times 100$

Note: $d$ is between the clamps of the sample holder before or after the sample is pulled to break. 


\section{RESULTS AND DISCUSSIONS}

\section{Characteristics of Cassava Peel Starch}

In this study, the raw material analysis of cassava peel starch included parameters of moisture content, starch content, amylose content, amylopectin content, and HCN content. It can be seen the results of the analysis of the characteristic parameters of cassava peel starch (Table 1). The drying process is very influential on the water content produced. The larger the surface area (area) of the raw material commodity, the faster the airflow around the commodity so that evaporation occurs fastly and starch with low water content is produced. Different drying processes cause the difference in high and low water content in starch; both methods and drying time can significantly affect starch moisture content (Setiani et al., 2013). In this study, the water content of cassava peel starch was $14.62 \%$, so that in this study, the water content in cassava peel starch followed national standards. The results of research Alfian (2020) showed that the water content in cassava peel starch was $11.13 \%$ after testing. According to the quality standard (National Standardization Council, 1994), the water content of cassava or cassava starch and its parts is a maximum of $17 \%$.

Starch content is one of the quality criteria for flour and starch products-the results of our analysis of cassava peel starch content of $73 \%$. This is also following the study by (Mudaffar, 2020), cassava peel starch has a starch content of $93.46 \%$. Starch contains a certain amount of linear and branched fractions. The linear fraction is amylose, while the rest is amylopectin. The amylose content of cassava peel starch was $21.02 \%$, while the amylopectin content of air tuber starch was $52.27 \%$.

The analysis of amylose content in cassava peel was $21.02 \%$, while the amylopectin content of cassava peel starch was $52.27 \%$. The result of measuring the amylose content in cassava peel starch was $21.02 \%$, the rest was amylopectin, which indicated that the amylose content in cassava peel was smaller than amylopectin. Similar results were also reported in (Pratiwi et al., 2016) research; amylopectin levels were obtained at $44.83 \%$. Amylopectin can be separated from amylose by dissolving starch in hot water below the gelatinization temperature. The dissolved fraction in hot water is amylose, and the insoluble fraction is amylopectin. The existence of differences in amylose and amylopectin can affect the solubility and degree of gelatinization of starch. Where amylopectin has an essential role in the gelatinization process, and high amylose content in starch can reduce gelatinization in starch (Nisah, 2017). According to (Winarti, 2012), the stability of edible films is influenced by amylopectin, while amylose affects its compactness with high amylose content resulting in edible films that are flexible and strong, the formation of a matrix between polymers is increasing so that the strength of hydrogen bonds between molecular chains in the film metric is also increasing. Furthermore, finally, a solid and compact film will be formed.

The level of $\mathrm{HCN}$ in this study was 7.01 ppm. HCN can be reduced/eliminated during the processing because it is easily soluble in water (Luthfi et al., 2012). The content of HCN in cassava peels is very high, which is $18.0-$ 309 ppm per 100 grams of cassava peel (Richana, 2013). The quality standard of cassava flour stipulates a maximum $\mathrm{HCN}$ content of $40 \mathrm{ppm}$ (BSN, 1996). The study results (Senja, 2018) decreased HCN levels after processing, among others, by washing, drying, and fermentation. Previous research conducted by (Bulan et al., 2012) found that $\mathrm{HCN}$ levels of $22.14 \mathrm{mg} / \mathrm{kg}$ or $22.14 \mathrm{ppm}$ are higher than this study. The presence of soaking and washing causes tissue damage so that the tissue becomes soft and $\mathrm{HCN}$ toxic compounds diffuse out because water will hydrolyze the linamarin compound and form cyanide soluble in water, and if the soaking water is replaced, the water-soluble $\mathrm{HCN}$ compounds will be wasted (Sari, 2018). Based on FAO (Food Agriculture Organization, 2013), food with an HCN content of $40 \mathrm{ppm}$ is safe for human 
consumption. Thus, the research results for cassava peel starch are safe for consumption.

\section{Physical and Mechanical Properties of Cassava Peel Starch Film}

\section{Thickness}

Based on the analysis of variance, the starch concentration of cassava peel had a significant effect on the thickness of the edible film $(P<0.05)$. The average thickness value can be seen in (Table 2). The average value of the thickness of the edible film with various concentrations ranged from 0.09 to $0.17 \mathrm{~mm}$. The highest thickness value is found in $6 \%$ starch concentration with a thickness value of $0.17 \mathrm{~mm}$, while the lowest is found in starch with a concentration of $2 \%$ with a thickness value of $0.09 \mathrm{~mm}$ due to the higher the concentration can increase the thickness and stability of the edible film. The average thickness value in this study follows the standard, namely a maximum of $0.25 \mathrm{~mm}$ (JIS, 1975). A study conducted (Cahyo et al., 2021) reported that the highest value of red bean starch edible film thickness was found at a concentration of $6 \%$ with a thickness value of $0.186 \mathrm{~mm}$; an increase in red bean starch concentration caused the thickness of the edible film to increase. Factors cause the thickness of the edible film, such as the number of ingredients used, the nature of the material, the size of the printing plate used in the drying process (Maharani, 2017). The number of material components in the manufacture of edible films also causes the resulting edible film to be thicker because there are very diverse constituent components of the material. According to (Warkoyo et al., 2014), high starch concentration can increase the polymer that makes up the edible film matrix, and the total solids of the edible film are large, resulting in a more significant edible film.

\section{Tensile strength}

The results of the ANOVA test showed that the addition of starch concentration of cassava peel had no significant effect on the tensile strength of the edible film $(P>0.05)$. The average tensile strength value of edible film with different concentrations of cassava starch can be seen in (Figure 1).

The average tensile strength of the edible film in this study ranged from 0.08 to $0.37 \mathrm{Mpa}$ (Figure 1). The addition of cassava starch had no significant effect on the tensile strength of the edible film because the administration of each treatment has a minimal difference so that it significantly produces a tensile strength that is not different. According to (Siregar, 2012), mechanical properties are influenced by a large amount of content of the components that make up the starch film and glycerol, so that the addition of glycerol causes the tensile strength value to decrease along with the increase in glycerol concentration because the addition of starch is getting bigger, the matrix of the film formed will also be more and more. (Warkoyo et al., 2014) concluded that the greater the addition of starch, the more the matrix structure formed, and the stronger the film matrix structure so that it is more vital to support the load. Resistance to damage due to stretching and stress can indicate that edible films have high tensile strength. This study's average tensile strength value was not following the standard, which was at least 0.39 $\mathrm{mm}$ (JIS, 1975). The low value of the tensile strength produced can be due to the edible film's active ingredients, making it challenging to transfer positions between molecules (Warkoyo et al., 2014). The addition of fatty acids into the edible film hydroxypropyl methylcellulose (HPMC) causes a decrease in the value of the resulting tensile strength (Jiménez et al., 2010) in a study (Muslimah et al., 2021), the tensile strength value of edible film from okra gel: aquades with 1:0 treatment had the highest tensile strength value of 1.04 $\mathrm{MPa}$. The concentration level of okra gel will increase the tensile strength produced.

\section{Elongation}

The results of analysis of variance on the elongation parameter addition of starch concentration of cassava peel did not significantly affect the elongation value of edible film ( $P>0.05)$. The average value of 
edible film elongation with different concentrations of cassava starch is described in Figure 2.

The average elongation value of edible film with various concentrations ranged from 31.86 to $56.43 \%$ (Figure 2 ). The addition of cassava starch had no significant effect on the elongation value of the edible film because the administration between treatments only experienced a slight difference, resulting in elongation that was not significantly different. However, an increase in glycerol will produce an edible film with a higher percentage of elongation within the limits of the edible film that is not soft because an increase in the amount of glycerol will reduce the strength of the intermolecular forces so that the mobility between the molecular chains increases and the percentage of edible film elongation increases (Siregar, 2012). On the other hand, an increase in starch concentration can cause a decrease in the elongation value due to the components that make up the edible film, the greater the addition of concentration, the lower the plasticizing film will result so that the elongation value decreases. (Pradipta et al., 2020) found that elongation changes can be seen when the edible film is torn; the amount of concentration added influences the percent elongation; the more starch concentration used, the lower the percent elongation produced. The decrease in elongation value can also be caused by cassava peel starch which contains high enough amylose to strengthen the viscosity and the total dissolved solids to be high; therefore, the matrix bond in the edible film is getting stronger and causes the elongation value to decrease. The average elongation value of edible film with a concentration of $2 \%$ has the best value compared to concentrations of $4 \%$ and $6 \%$, which is following the standard, namely $<10 \%$ is terrible and $>50 \%$ is excellent (JIS, 1975).

The elongation percentage determines the elasticity of an edible film, a high percentage of elongation causes the edible film to become elastic. Glycerol functions are as a plasticizer that can reduce the cohesion of mechanical bonds between polymers and change its rigidity so that the edible film becomes elastic. Adding the added glycerol concentration can reduce the intermolecular forces so that the mobility between the polymer molecular chains increases. In the study reported (Muslimah et al., 2021), the highest elongation value was obtained at the addition of $2.5 \%$ starch concentration, while the lowest elongation value was found in the addition of $5 \%$ starch concentration. The higher the elasticity level indicates that the edible film will be easier to use because it has a high flexibility value. The higher the concentration of cassava starch, the lower the elongation of the edible film produced.

\section{Water Vapor Transmission Rate (WVTR)}

The statistical analysis results showed that the addition of starch concentration of cassava peel had no significant effect on the WVTR value of edible films $(P>0.05)$. The average value of WVTR edible film with different concentrations of cassava starch is described in Figure 3. WVTR values of edible films with various concentrations ranged from 0.26 to $0.39 \mathrm{~g} / \mathrm{m} 2 /$ day (Figure 3 ). The average value of WVTR has met the Japanese Industrial Standard (1975), which is $<7 \mathrm{~g} / \mathrm{m} 2 / 24$ hours. The addition of cassava starch had no significant effect on the value of the water vapor transmission rate of the resulting edible film because the bonding forces between polymers are getting more robust with the increase in the concentration of cassava starch used. Pramadita (2011) stated that increasing the inter-polymer force will reduce the transmission of water vapor of the edible film to gas, vapor, and porosity so that the function of the edible film as a barrier to the entry of water vapor will increase. Increasing the concentration of cassava starch in the manufacture of edible films will reduce the water vapor transmission of the edible films produced due to the more significant the total solids of the edible film so that there is less chance of water entering the film. According to Olivato, et al. (2012) in (Muslimah et al., 2021), 
the decrease in water vapor permeability is due to the reduced movement of the polymer chains, making it difficult for water diffusion through the edible film. The thickness of the edible film also influences the WVTR value. The thicker the film will increase the rate of water vapor. Similar results with (Ginting, 2012) research that thickness can affect the rate of water vapor, gas, and other volatile compounds. The thicker the edible film produced will increase its ability to inhibit the rate of gas and water vapor to extend the shelf life of food products. In the study reported (Saputro et al., 2017), the addition of the concentration of cassava starch causes the water vapor transmission to tend to decrease, this is because the water vapor transmission of the glucomannan-maize composite film is lower than the edible film of the glucomannancassava starch composite that has been studied. The water vapor transmission rate of tapioca glucomannan edible film ranged from 19.43 to $21.64 \mathrm{~g} / \mathrm{m} 2 /$ day.

\section{CONCLUSIONS}

The analysis of the characteristics of the raw material of cassava peel starch obtained starch content, amylose content, amylopectin content, and HCN content that met the standard. The addition of a high concentration of cassava peel starch caused an increase in the thickness and tensile strength parameters but caused a decrease in the WVTR and elongation parameters.

\section{ACKNOWLEDGMENT}

Acknowledgment to the Ministry of Education and Culture of the Republic of Indonesia for funding with No. Contract: 1949/E2/KM.05.01/2021.

\section{REFERENCES}

Andi Alfian, Dewi Wahyuningtyas, P. D. S. (2020). Pembuatan Edible Film Dari Pati Kulit Singkong Menggunakan Plasticizer Sorbitol Dengan Asam Sitrat Sebagai Crosslinking Agent (Variasi Penambahan Karagenan Dan Penambahan Asam Sitrat). Jurnal Inovasi Proses, 5(2).
BPS. 2015. Produksi Ubi Kayu Menurut Provinsi (Ton) 1993-2015. Badan Pusat Statistik.Https://Www.Bps.Go.Id/Linktable dinamis/View/ld/880 Diakses Tanggal 23 September 2021.

Cahyo, N. A. D., Warkoyo, W., \& Anggriani, R. (2021). Karakteristik Fisik Dan Mekanik Edible Film Berbasis Pati Kacang Merah (Phaseoulus Vulgaris) Dan Gel Okra (Abelmoschus Esculentus L). Food Technology And Halal Science Journal, 4(1), 82-93. Https://Doi.Org/10.22219/Fths.V4i1.1565 5

Ginting, R. Y. Dan E. (2012). Perbedaan Karakteristik Fisik Edible Film Dari UmbiUmbian Yang Dibuat Dengan Penambahan Plasticizer. Penelitian Pertanian Tanaman Pangan Vol., 31(1990), 131-136.

Irzam, F. N., \& Harijono. (2014). The Effect Of Water Replacement And Use Of Nahco 3 In Soaking Cassava Slices ( Manihot Esculenta Crantz ) Against Cyanide Levels In Cassava Flour Processing. Jurnal Pangan Dan Agroindustri, 2(4), 188-199.

Http://Jpa.Ub.Ac.Id//Index.Php/Jpa/Article/ View/91

Luthfi, A., Wijaya, A., Murwono, I. R. P. D., Kimia, J. T., Teknik, F., Diponegoro, U., Sudharto, J. P., \& Fax, T. (2012). Penghilangan Hcn Dalam Umbi Gadung Dengan Menggunakan Bahan Penyerap Abu. Jurnal Teknologi Kimia Dan Industri, 1(1), 14-20.

Mudaffar, R. A. (2020). Karakteristik Edible Film Dari Limbah Kulit Singkong. Tabaro, 4(2), 473-483.

Muslimah, S. M., Warkoyo, W., \& Winarsih, S. (2021). Studi Pembuatan Edible Film Gel Okra (Abelmoschus Esculentus L.) Dengan Penambahan Pati Singkong. Food Technology And Halal Science Journal, 4(1), 94-108. Https://Doi.Org/10.22219/Fths.V4i1.1582 6

Nisah, K. (2017). Study Pengaruh Kandungan Amilosa Dan Amilopektin Umbi-Umbian Terhadap Karakteristik Fisik Plastik 
Biodegradable Dengan Pendahuluan Lastik Biodegradable Merupakan Plastik Yang Dapat Terurai Oleh Aktivitas Mikroorganisme Plastik Biodegradable Memiliki Kegun. 5(2), 106-113.

Pradipta, Akhdan Rifqi, Irawati, Dery Junika, N. (2020). Inovasi Plastik Biodegradable Dengan Karakteristik Edible Film Dari Bonggol Pisang Dan Limbah Kulit Singkong Dengan Plasticizer Gliserol. Jurnal IImiah Penalaran Dan Penelitian Mahasiswa, 4(2), 154-162.

Pratiwi, P. A., Kimia, P. S., Sains, F., Teknologi, D. A. N., \& Hidayatullah, U. I. N. S. (2016). Karakteristik Dan Kualitas Edible Film Pati Talas ( Colocasia Esculenta) Sebelum Dan Setelah.

Richana N. 2012. Ubi Kayu Dan Ubi Jalar. Botani, Budidaya, Teknologi Proses,Teknologi Pascapanen. Penerbit Nuansa. Bandung

Saputro, B., Dewi, E., \& Susanto, E. (2017). Karakteristik Edible Film Dari Campuran Tepung Semirefined Karaginan Dengan Penambahan Tepung Tapioka Dan Gliserol. Jurnal Pengolahan Dan Bioteknologi Hasil Perikanan, 6(2), 1-6.

Sari, Fi. D. N., \& Astili, R. (2018). Kandungan Asam Sianida Dendeng Dari Limbah Kulit Singkong. Jurnal Dunia Gizi, 1(1), 20. Https://Doi.Org/10.33085/Jdg.V1i1.2899

Siregar, S. H., \& Irma, W. (2012). Pemanfaatan Kulit Singkong Sebagai Alternatif Bahan Baku Edible Film. Photon: Jurnal Sain Dan Kesehatan, 3(1), 15-21. Https://Doi.Org/10.37859/Jp.V3i1.144

Tri Puji Rahayu, Candarisma Danes Noor Viana, Zahrotul Luklukyah, B. I. (2019). Potensi Daya Dukung Limbah Kulit Singkong Hasil Olahan Pothil Sebagai Pakan Sapi Potong Di Kecamatan Dukun, Magelang. B A A R Bulletin Of Applied Animal Research, 1(September), 1-4.

Warkoyo ,Rahardjo, B., Wiseso Marseno, D., \& Nugroho Wahyu Karyadi, J. (2014). Sifat Fisik, Mekanik Dan Barrier Edible Film Berbasis Pati Umbi Kimpul (Xanthosoma Sagittifolium) Yang Diinkorporasi Dengan Kalium Sorbat Physical, Mechanical And
Barrier Properties Of Xanthosoma Sagittifolium Starch-Based Edible Film Incorporated With Po. Agritech, 34(1), 72 81.

Winarti, C. (2012). Production Technology And Application Of Starch BasedAntimicrobial Edible Package. J. Litbang Pertanian, 31(3), 85-93.

Wulandari, K., Sulistijowati, R., \& Mile, L. (2015). Kitosan Kulit Udang Vaname Sebagai Edible Coating Pada Bakso Ikan Tuna. Jurnal IImiah Perikanan Dan Kelautan, 3(September), 118-121.

Y. Bulan, Y., Nst, R. B., \& Alfian, Z. (2012). Pemanfaatan Kulit Ubi Kayu Menjadi Kerupuk Dan Penentuan Kadar Nutriennya. Photon: Jurnal Sain Dan Kesehatan, 2(2), 63-69. Https://Doi.Org/10.37859/Jp.V2i2.141

Yudiyanti, I., \& Matsjeh, S. (2020). Aplikasi Edible Coating Pati Kulit Singkong (Manihot utilisima Pohl.) pada Tomat (Solanum Lycopersicum L.) serta Uji Kadar Total Fenol dan Kadar Vitamin C sebagai Sumber Belajar. Biodik, 6(2), 5361. https://doi.org/10.22437/bio.v6i2.9260

Yulia Maharani, F. H. dan R. (2017). Pengaruh Perlakuan Sodium Tripolyphosphate (Stpp) Pada Pati Sagu Termodifikasi Terhadap Ketebalan, Transparansi Dan Laju Perpindahan Uap Air Edible Film. The Abundance of Toxic Dinoflagellate Gambierdiscus Sp, Ostereopsis Sp and Prorocentrum $S p$ on Seagrass Leaf Thalassia Sp from the Nirwana Beach West Sumatera Province By:; 1(2), 1-6. 
Wasistha, et al., 2021

APPENDIX.

Table 1. Characteristics of Cassava Peel Starch

\begin{tabular}{lc}
\hline \multicolumn{1}{c}{ Parameter } & Value \\
\hline Water Content (\%) & 14,62 \\
Starch Content (\%) & 73,29 \\
Amylose Content (\%) & 21,02 \\
Amylopectin Content(\%) & 52,27 \\
HCN (ppm) & 7,01 \\
\hline
\end{tabular}

Table 2. Thickness of Edible Film based on Peel cassava starch

\begin{tabular}{cc}
\hline Concentration of Peel cassava starch $(\%)$ & Thickness $(\mathrm{mm})$ \\
\hline 2 & $0,09^{\mathrm{a}}$ \\
4 & $0,16^{\mathrm{b}}$ \\
6 & $0,17^{\mathrm{b}}$
\end{tabular}

Note: The numbers in the same row followed by the same letter are not significantly different $(p>5 \%)$

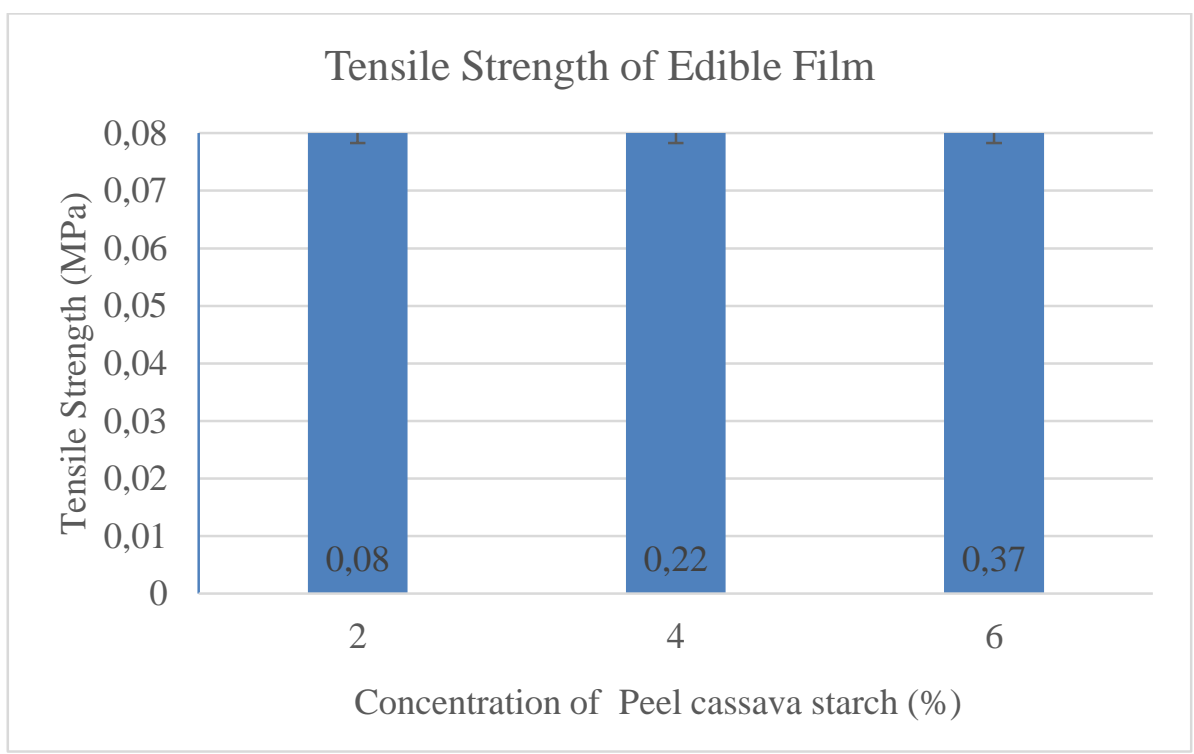

Figure 1. Histogram of the average value of thickness

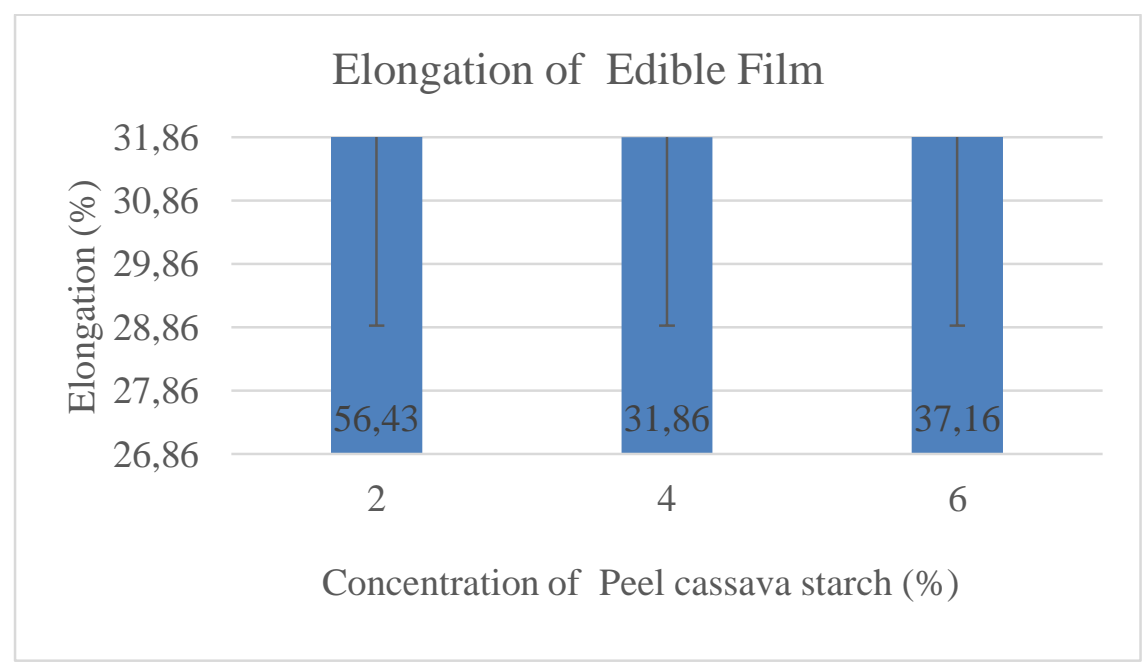


Wasistha, et al., 2021

Figure 2. Histogram of the average value of percent elongation.

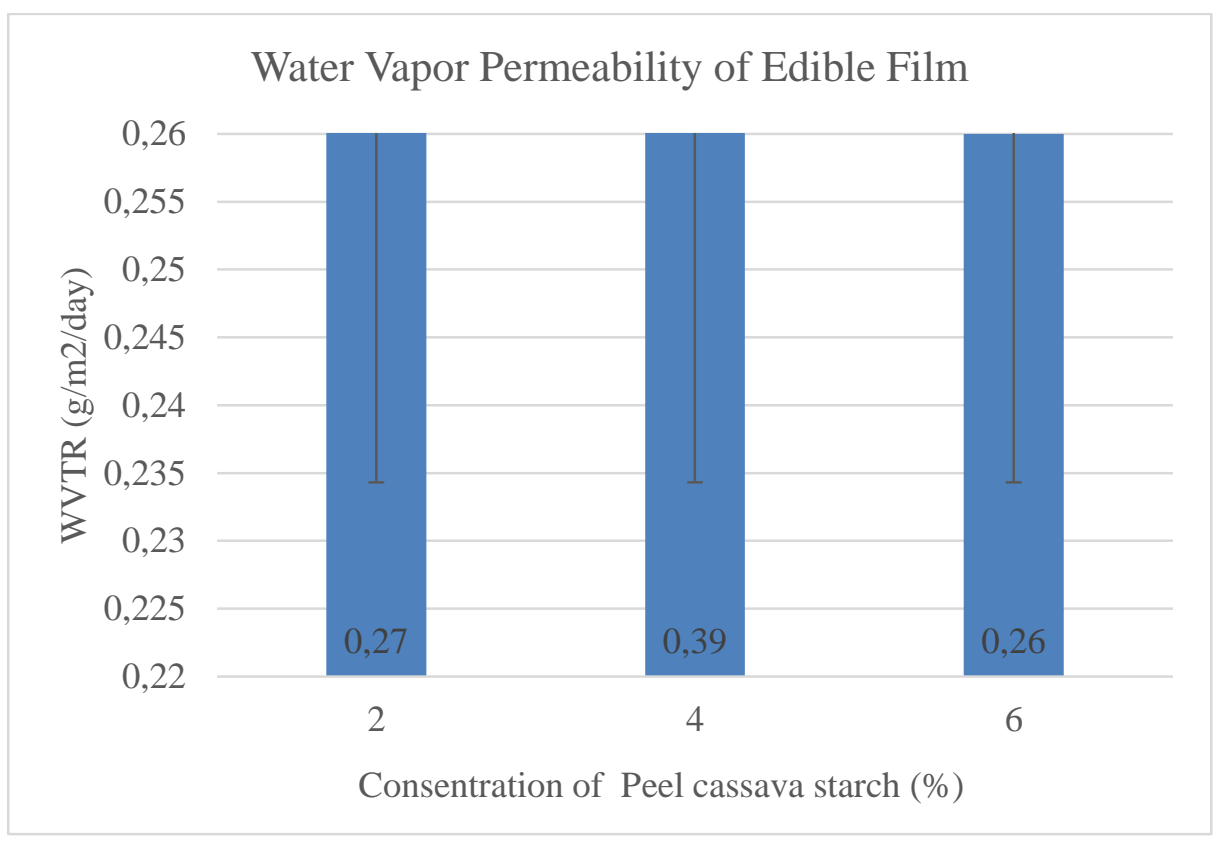

Figure 3. Histogram of the average value of the water vapor transmission rate

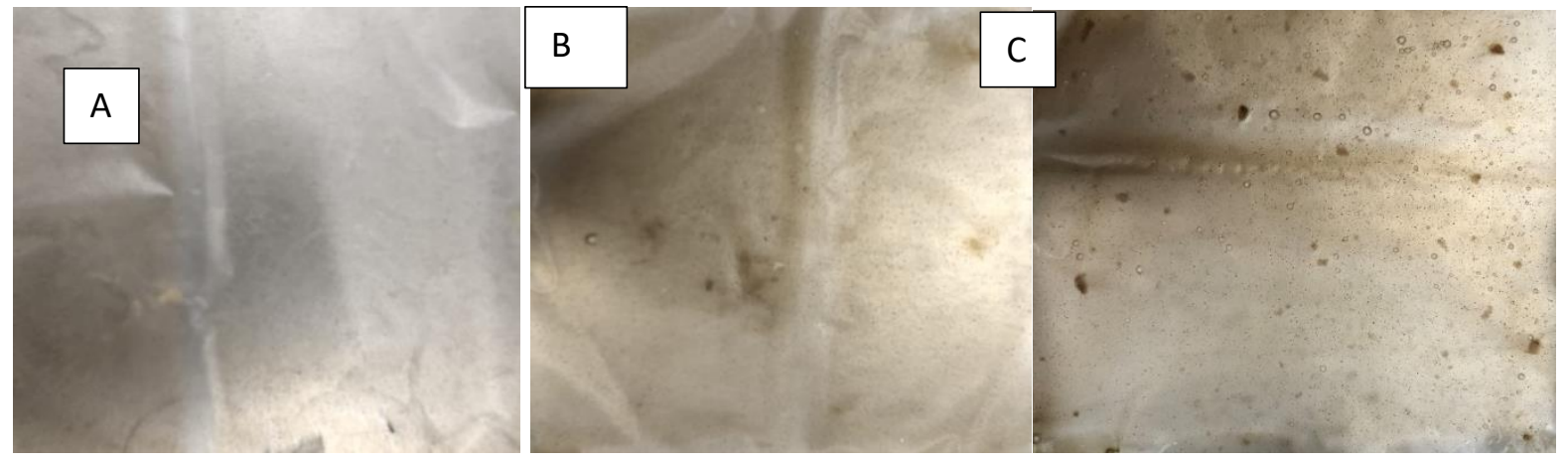

Figure 4. The appearance of the edible film based on various concentration of cassava peel starch $A=2 \%, B=4 \%$ and $C=6 \%$ 